\title{
Is Barnier het juiste antwoord op de vraag van de maatschappij naar een kritische accountant die
}

\section{zekerheid geeft over de financiële stabiliteit van een onderneming?}

Barbara Majoor

SAMENVATTING De maatschappij zet vraagtekens bij het werk van de accountant. Is een accountant wel in staat om de maatschappij het benodigde vertrouwen te geven in de financiële stabiliteit van een onderneming? Barnier stelt in zijn Green Paper over de benodigde hervorming van het accountantsberoep (European Commission, 2010) als gevolg van de bankencrisis de terechte vraag of de controlefunctie moet worden versterkt, zodat in de toekomst nieuwe (financiële) risico's kunnen worden beperkt. In dit artikel wordt geconcludeerd dat de huidige rolinvulling onvoldoende aansluit op de breedheid in vraagstukken van diverse groepen stakeholders met name waar het de financiële stabiliteit van een onderneming betreft. Het antwoord van Barnier daarop is eveneens onvoldoende, omdat te veel de nadruk ligt op de bestaande rolinvulling en te weinig aandacht wordt gegeven aan de differentiatie in informatiebehoeften van de diverse groepen stakeholders.

RELEVANTIE VOOR DE PRAKTIJK De voorstellen voor hervorming van het accountantsberoep hebben een ingrijpende impact op het functioneren van accountants en de accountantsmarkt in brede zin. Dit artikel geeft inzicht of de voorstellen van de Europese Commissie bijdragen aan een versterking van de maatschappelijke rol of juist niet. Daarmee geeft dit artikel een bijdrage aan de discussie of de voorstellen van de Commissie voldoende zijn om het maatschappelijk vertrouwen te herstellen.

\section{Inleiding}

Doet de accountant zijn werk wel goed als het gaat om de controle van de boeken of om het signaleren van risico's die de continuitteit van een onderneming bedreigen? Met regelmaat worden dergelijke vragen gesteld. De Commissie de Wit (2010b) stelt de vraag of de accountant zijn maatschappelijke taak heeft kunnen waarmaken bij de controle van banken en financiële instellingen door gebruikers in voldoende mate te wijzen op de risico's die in de balansen van banken waren opgenomen. Barnier komt in zijn Green Paper met diverse voorstellen om de reikwijdte en aanpak van de controle aan te passen.

In dit artikel worden de voorstellen van Barnier besproken vanuit de vraagstelling die in het maatschappelijk debat wordt opgeroepen of de accountant voldoende haar rol oppakt waar het gaat om zekerheid te geven over de financiële stabiliteit van een onderneming, vooral waar het gaat om een versterking van de signalerende rol met betrekking tot (financiële) risico's. Dit artikel is als volgt opgebouwd. Eerst wordt de maatschappelijke betekenis van accountants toegelicht vanuit een historisch perspectief om de fundamenten waarop het maatschappelijk vertrouwen steunt te benoemen. Daarna wordt in paragraaf 3 de vraag beantwoord of de voorstellen van de Europese Commissie het juiste antwoord zijn om het accountantsberoep te hervormen en wordt in paragraaf 4 de vraag beantwoord of de voorstellen bijdragen aan het versterken van de kwaliteit van de controle. Ten slotte wordt in de laatste paragraaf stilgestaan bij enkele voorstellen voor verbreding van de rol van de accountant die een eerste aanzet zijn voor het geven van een oordeel door de ac- 
countant over de financiële stabiliteit van een onderneming.

\section{De maatschappelijke betekenis van accountants in historisch perspectief}

\subsection{Inleiding}

De accountant levert zijn primaire bijdrage aan het maatschappelijk verkeer door het toevoegen van zekerheid over de financiële stabiliteit van een onderneming. De behoefte aan zekerheid vindt zijn wetenschappelijke ontstaansgrond in de agencytheorie (Watts en Zimmerman, 1983), op basis van de uitgangspunten van belangentegenstellingen en informatieachterstand tussen eigenaar en bestuurders. In deze theorie wordt de accountant beschouwd als monitor in opdracht van de eigenaren van een onderneming om een onafhankelijke toets uit te voeren op de activiteiten van de bestuurders en de informatie die zij aan de eigenaren aanleveren. Dit moet bijdragen aan het handhaven van het vertrouwen van de eigenaren in de bestuurders en daarmee in de borging van hun (financiele) belangen in de onderneming.

De wortels van de controle zijn door de historicus Richard Brown in 1905 als volgt beschreven: "The origin of auditing goes back to times scarcely less remote than that of accounting... Whenever the advance of civilization brought about the necessity of one man being entrusted to some extent with the property of another the advisability of some kind of check upon the fidelity of the former would become apparent".

Limperg, de grondlegger van het Nederlandse accountantsberoep, definieert in zijn theorie (Limperg, 1932/1933) stakeholders breder dan in de agencytheorie en spreekt over het maatschappelijk verkeer. Limperg maakt geen onderscheid in verschillende groepen stakeholders. Hij baseert evenals de agencytheorie de vraag naar controle op het uitgangspunt van het bestaan van een belangentegenstelling tussen de ondernemingsleiding en het brede maatschappelijk verkeer, met als risico dat de informatie die de ondernemingsleiding verstrekt niet betrouwbaar is. De invulling van de rol van de accountant heeft zich op basis van dit uitgangspunt ontwikkeld tot de uitvoering van de controle van de jaarrekening zoals die tot vandaag is vastgelegd in Boek 2 BW (art. 2:393 BW) waarin de taak van de accountant bij de wettelijke controle is beschreven.

\subsection{Vertrouwen: basis voor de dienstverlening door accountants}

Het bestaansrecht van het accountantsberoep is enerzijds afhankelijk van het adequaat beantwoorden van de vraagstukken van stakeholders zoals hierboven toegelicht. Deze maatschappelijke rol is door Limperg reeds als volgt verwoord: "De maatschappelijke functie van de accountant bestaat hieruit, dat de samenleving een vertrouwen in hem of haar stelt om als onafhankelijke deskundige de betrouwbaarheid van informatie vast te stellen die van belang is voor het maatschappelijk verkeer" (Limperg, 1974).

Anderzijds is dit bestaansrecht afhankelijk van het vertrouwen dat de maatschappij heeft dat accountants hun taak 'a priori' goed kunnen invullen. Limperg verwoordt dit vertrouwen in 1926 als volgt: "Er mag geen groter vertrouwen in de functie van de accountant worden gesteld dan gerechtvaardigd wordt door de verrichte arbeid en de deskundigheid van de accountant en omgekeerd moet de functie worden vervuld op de wijze die het in haar vervulling gestelde vertrouwen rechtvaardigt".

Vooral de laatste zin "de wijze die het in haar vervulling gestelde vertrouwen rechtvaardigt" is nog steeds de kernpassage voor de claim van de maatschappij dat een accountant in haar functioneren continu alert moet zijn op wat de maatschappij ziet en vindt van de kwaliteit van de dienstverlening. De kwaliteit van de dienstverlening wordt enerzijds bepaald door de inhoud van de dienstverlening zoals deze wordt waargenomen door de maatschappij en anderzijds door de onafhankelijkheid waarmee de dienstverlening wordt uitgevoerd (DeAngelo, 1981).

\subsection{Verbreding en differentiatie in informatiebehoeften van stakeholders}

De agencytheorie en de theorie van Limperg zijn nog steeds de gangbare verklaring voor de hedendaagse rolinvulling van accountants en de verwachtingen die de maatschappij stelt aan hun functioneren. Waar in de klassieke agencytheorie slechts sprake is van één 'stakeholder' (de eigenaar) en in de theorie van Limperg het maatschappelijk verkeer niet verder is uitgewerkt, is er in de loop van de tijd in de agencytheorie (Jensen en Meckling, 1976) een differentiatie ontstaan in de groepen stakeholders die belang hebben bij een onafhankelijke toets op de activiteiten van de bestuurders van een onderneming. Deze stakeholders omvatten enerzijds de interne stakeholders zoals commissarissen en werknemers en anderzijds externe stakeholders, zoals overheden, leveranciers en het brede publiek. Waar de eigenaar met name gericht was op een toets of de bestuurder als gevolg van eigenbelang de informatie onvolledig en/of onjuist aan de eigenaar rapporteert, hebben andere stakeholders ook andere informatiebehoeften als basis voor hun vertrouwen in ondernemingen.

Deze differentiatie in de groepen stakeholders ten opzichte van het oorspronkelijke agencymodel brengt een aantal consequenties met zich mee die van invloed zijn op de context en reikwijdte van de controle. Een belangrijke consequentie is dat de vragen die bij deze diverse stakeholdergroepen leven ten aanzien van het vertrouwen in een onderneming anders en breder zijn dan uitsluitend de eigenaar-bestuurdervraagstukken die de basis van de agencytheorie en de theorie van Limperg vormen. 
In het rapport van de Commissie Cohen eind jaren zeventig van de vorige eeuw (Cohen Commission, 1978) wordt deze verbreding in vragen van stakeholders, die belangrijk zijn voor hun vertrouwen in ondernemingen, ook als belangrijke oorzaak onderkend voor het afnemen van het maatschappelijk draagvlak voor de functie van de accountant. De commissie signaleert een verschil tussen wat accountants menen dat hun functie is en wat de verschillende gebruikers van de dienstverlening verwachten van de dienstverlening. Ook in de toelichting van de SarbanesOxley-wet (2002) wordt dit aspect nadrukkelijk benoemd en is deze verwachtingskloof de reden dat aan de Public Company Accounting Oversight Board (PCAOB) de taak wordt gegeven om de wijze waarop de accountants hun rol invullen te bepalen. "That task is now in the hands of the $\mathrm{PCAOB}$, and the Board's charge effectively requires it to be responsive to the public perception of the assurance that society needs and reasonably expects from an audit" (Carmichael, 2004).

Samenvattend kan worden geconcludeerd dat de historie leert dat de maatschappij leidend is voor de gewenste rolinvulling door accountants. Met als startpunt de agencytheorie met slechts één stakeholder (de aandeelhouder) die een beperkte vraagstelling had, heeft de maatschappelijke vraag zich ontwikkeld naar een model met diverse groepen stakeholders met gedifferentieerde vraagstelling ten aanzien van hun vertrouwen in de financiële stabiliteit van een onderneming.

Tevens kan worden vastgesteld dat de norm die de maatschappij stelt aan de invulling van deze functie niet statisch is, maar zich in voortdurende wisselwerking zou moeten aanpassen. "In other words, changes in the needs of society and changes in auditing methods combine to result in changes in the auditor's function" (Carmichael, 2004).

De vraag die kan worden gesteld, is of accountants in voldoende mate zijn meegegroeid met deze differentiatie in de vraagstelling van stakeholders (zie o.a. Cohen Commission, 1978). De vraag komt bijvoorbeeld op of de verklaring van de accountant in voldoende mate de diverse vragen van stakeholders die belangrijk zijn voor hun vertrouwen in de financiële stabiliteit van een onderneming heeft beantwoord. Bijvoorbeeld op het gebied van het verschaffen van inzicht in de strategie en risico's van een onderneming.

In diverse rapporten over het functioneren van accountants tijdens de financiële crisis wordt hieraan getwijfeld (Commissie Maas, 2009; Commissie de Wit, 2010a, 2010b; European Commission, 2010). Zo overweegt de Commissie Maas ten aanzien van de externe rol van accountants: "De toegevoegde waarde van de controle van de accountant op de financiële en operationele activiteiten van een bank, dient verhoogd te worden. Daarnaast is hernieuwde aandacht nodig voor de rolverdeling en samenwerkingsmogelijkheden tussen de toezichthouders en de externe accountant (Commissie Maas, 2009, p. 16).”

Ook in andere studies waaronder studies door de Economic Affairs Committee (2011) en de International Auditing and Assurance Standards Board (IAASB, 2011) wordt onderkend dat de informatiebehoefte van de verschillende groepen stakeholders en hun behoeften aan zekerheid over het functioneren van ondernemingen zich hebben ontwikkeld onder invloed van de toenemende complexiteit en globalisering van de economie. "Today's increasingly global and complex business environment and the turbulent events of the global financial crisis have highlighted the critical importance of credible, high-quality financial reporting. The current environment and events also have stimulated the demand for additional, and more pertinent, information about entities and the processes that support the quality of their financial reporting. Existing shareholders, potential investors and others look to reduce the level of uncertainty in their decisions by seeking information they consider to be relevant and reliable" (IAASB, 2011).

\section{Geven de voorstellen van Barnier een adequaat antwoord op de gewijzigde maatschappelijke verwachtingen over de rolinvulling door accountants?}

De gewijzigde verwachtingen van de maatschappij over de invulling van de rol van de accountant komen mede onder invloed van de financiële crisis naar boven.

Barnier duidt in zijn Green Paper (European Commission, 2010) diverse vraagstukken waarop de kwaliteit van de controle tekortschiet. Barnier draagt hiervoor een aantal oorzaken aan die in figuur 1 zijn opgenomen.

\section{Figuur 1 Problem tree (gedeeltelijk)}

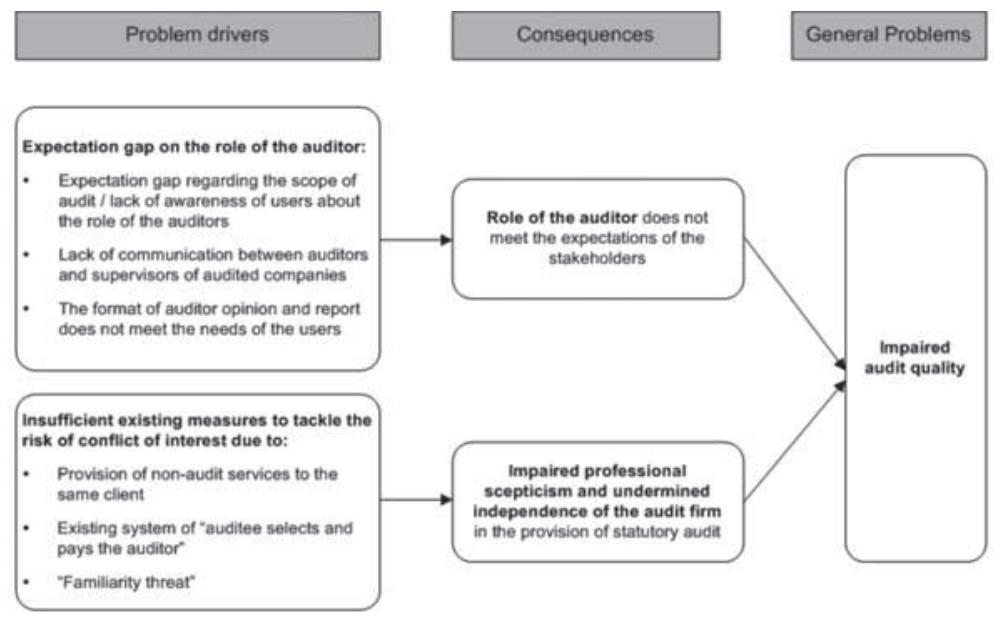

Figuur ontleend aan Impact assessment (European Commission, 2011f). 
Het tekort aan controlekwaliteit vindt volgens Barnier voor een belangrijk deel zijn oorzaak in een te beperkte takkopvatting door de accountant. Een mening over onderwerpen zoals potentiële toekomstige risico's voor de continuïteit, ontwikkelingen in de sector en grondstoffenen wisselkoersrisico's als onderdeel van de controleverklaring, hebben een belangrijke meerwaarde voor de externe stakeholders in aanvulling op een retrospectief oordeel over de verantwoording. Ook de invulling van de rol naar interne gebruikers schiet in de visie van Barnier tekort. Barnier is in zijn Green Paper bovendien van mening dat accountants onvoldoende rapporteren aan de interne toezichthoudende organen over fundamentele bevindingen tijdens de controle met betrekking tot de continuiiteitsveronderstelling van de bedrijfsactiviteiten en de daarmee verband houdende controlesystemen, de toekomstige ontwikkelingen en risico's waarmee de onderneming te maken krijgt, materiële toelichtingen, aangetroffen onregelmatigheden, gebruikte methoden inzake administratieve verwerking en eventuele transacties voor het 'flatteren van de balans' (European Commission, 2010).

Deze aspecten van het functioneren van ondernemingen die voor stakeholders belangrijk zijn voor het vertrouwen in de onderneming worden volgens Barnier onvoldoende in de huidige rol ingevuld. Barnier is hiermee niet uniek, ook in het rapport van de Commissie de Wit (2010a) gaat het vooral om toekomstgerichte informatie waar de accountant het laat liggen in zijn takinvulling. "De financiële crisis heeft duidelijk gemaakt dat de financiële verantwoordingsinformatie van financiële instellingen voor aandeelhouders en andere gebruikers van de jaarrekening ontoereikend is geweest om de grote risico's binnen de instellingen of het financiële systeem te zien. Het is voor veel mensen moeilijk te begrijpen dat de jaarrekeningen van financiële instellingen die zwaar in de problemen zijn gekomen wel in de voorafgaande jaren zijn voorzien van een goedkeurende accountantsverklaring. De controlerende accountants en de accountantsorganisaties zijn niet in staat geweest om te waarschuwen dat het voortbestaan van bepaalde banken ernstig gevaar liep of dat er grote risico's zaten in het financiële systeem" (Commissie de Wit, 2010b, pp. 167-168).

Behalve de inhoudelijke verwachtingskloof vindt Barnier dat er ook tekortkomingen zijn in de communicatie, zowel qua vorm als inhoud. Barnier stelt kritische vragen of accountants in voldoende mate in de verklaring gebruikers informeren over relevante feiten die bij de controle naar voren zijn gekomen. Ook is hij van mening dat accountants onvoldoende communiceren met toezichthouders over hun bevindingen. Daarnaast onderkent Barnier een gebrek aan professioneel-kritische instelling en onafhankelijkheid, wat een negatief effect heeft op de controlekwaliteit.
In het vervolg van dit artikel wordt verder ingegaan op de voorstellen die Barnier doet om de inhoudelijke verwachtingskloof en de verwachtingskloof ten aanzien van de communicatie te mitigeren en of deze een toereikend antwoord zijn. De mate van toereikendheid wordt beoordeeld vanuit het perspectief van de maatschappelijke verwachtingen over de rolinvulling door de accountant.

\section{Voorstellen van Barnier voor aanpassing van de maatschappelijke functie}

\subsection{Inleiding}

Barnier heeft op grond van zijn in de vorige paragraaf besproken probleemanalyse over de verwachtingskloof diverse voorstellen gedaan om de rolinvulling van de accountant aan te passen en daarmee de kwaliteit van de controle te versterken. Deze voorstellen zijn in tabel 1 samengevat.

\subsection{Bespreking van de maatregelen}

Wat opvalt is dat de voorstellen van de commissie zich sterk concentreren op de versterking van de onafhankelijkheid en professioneel-kritische instelling als randvoorwaarden voor het vertrouwen in de accountant en in beperkte mate op de werkelijke inhoudelijke behoeften aan informatie van de stakeholders.

Op grond van de impactanalyse (European Commission, 2011f) lijkt de keuze te zijn gemaakt om de rolinvulling van de accountant niet te verbreden, maar deze uitsluitend te verduidelijken via bijvoorbeeld een inkadering van wat wordt verstaan onder een professioneel-kritische instelling en versterking van de communicatie met de interne en externe stakeholders.

Dit laatste via verduidelijking van de reikwijdte van de wettelijke controle van financiële overzichten en de informatie die de accountant aan gebruikers, de gecontroleerde entiteiten, audit comittees en toezichthouders verstrekt.

De vraag dringt zich op of de voorstellen een oplossing bieden voor de verbreding in vraagstukken die leven bij stakeholders en die, zoals in paragraaf 2 besproken, andere eisen stellen aan de rolinvulling door de accountant. Deze vraag lijkt ontkennend te moeten worden beantwoord. Deze omissie is opmerkelijk omdat de commissie in de inleiding van haar Green Paper (European Commission, 2010) nadrukkelijk een bredere rol voor de accountant neerzet om de financiële stabiliteit van een onderneming te onderzoeken. "De Commissie wil op internationaal niveau de leiding in dit debat nemen en zal streven naar nauwe samenwerking met haar wereldwijde partners binnen de Raad voor Financiële Stabiliteit en de G2o. De auditfunctie moet, naast toezicht en corporate governance, een essentiële bijdrage leveren aan de financiële stabiliteit, want zij geeft zekerheid over de werkelijke financiële ge- 
Tabel 1

\begin{tabular}{|c|c|c|c|}
\hline $\begin{array}{l}\text { Verwachtingskloof over de rolinvulling } \\
\text { door de accountant }\end{array}$ & $\begin{array}{l}\text { Vragen in EC Green Paper (European } \\
\text { Commission, 2010) }\end{array}$ & $\begin{array}{l}\text { Opties die in aanloop naar voorstel } \\
\text { conceptregelgeving zijn overwogen } \\
\text { door EC (ontleend aan impact } \\
\text { assessment study, European Commis- } \\
\text { sion, 2011f) }\end{array}$ & $\begin{array}{l}\text { Voorstel in concept regelgeving van } \\
\text { toepassing op 'Organisaties van } \\
\text { Openbaar Belang' (OOB's) (Europese } \\
\text { Commissie, 2011a en b) }\end{array}$ \\
\hline $\begin{array}{l}\text { Reikwijdte van de rolinvulling sluit niet aan } \\
\text { bij de verwachtingen van gebruikers. }\end{array}$ & $\begin{array}{l}\text { - Moet de reikwijdte van de controle zich } \\
\text { uitstrekken tot een oordeel over de finan- } \\
\text { ciële gezondheid van ondernemingen? } \\
\text { - Moet de toegepaste controlemethode } \\
\text { beter aan gebruikers worden uitgelegd } \\
\text { teneinde de verwachtingskloof te over- } \\
\text { bruggen en de rol van de accountant te } \\
\text { verduidelijken? } \\
\text { - Denkt u dat auditors een rol zouden } \\
\text { moeten spelen in het garanderen van de } \\
\text { betrouwbaarheid van de informatie die } \\
\text { ondernemingen rapporteren op het gebied } \\
\text { van Maatschappelijk Verantwoord Onder- } \\
\text { nemen? }\end{array}$ & $\begin{array}{l}\text { 1. Verduidelijking van de reikwijdte van de } \\
\text { controle van OOB's, zonder de reikwijdte } \\
\text { te verbreden inclusief het specifiek maken } \\
\text { van de rolinvulling van de accountant bin- } \\
\text { nen deze reikwijdte. } \\
\text { 2. Een herdefiniëring van de reikwijdte van } \\
\text { de rolinvulling met name met betrekking } \\
\text { tot onderzoek van toekomstige informatie } \\
\text { (die verder gaat dan de continuliteit van } \\
\text { een onderneming). }\end{array}$ & $\begin{array}{l}\text { Optie } 1 \text { als voorstel voor wetgeving over- } \\
\text { genomen. }\end{array}$ \\
\hline $\begin{array}{l}\text { Communicatie tussen accountants en } \\
\text { andere toezichthouders op ondernemingen } \\
\text { is niet adequaat. }\end{array}$ & $\begin{array}{l}\text { - Is er een adequate en regelmatige dia- } \\
\text { loog tussen de externe auditors, de interne } \\
\text { auditors en het audit comittee? Als dit } \\
\text { niet het geval is, hoe kan deze communi- } \\
\text { catie dan worden verbeterd? } \\
\text { - Moet het tijdsinterval tussen het einde } \\
\text { van het boekjaar en de datum van de } \\
\text { controleverklaring worden verkleind, via } \\
\text { controle/beoordeling van tussentijdse cij- } \\
\text { fers? }\end{array}$ & $\begin{array}{l}\text { 1. Uitgebreide rapportage aan de interne } \\
\text { toezichthouders (audit committee) binnen } \\
\text { een onderneming over o.a.: continuïteit } \\
\text { van een onderneming en de potentiële } \\
\text { risico's op dat gebied, non-compliance } \\
\text { met regels, beoordeling van toegepaste } \\
\text { waarderingsmethoden, kwaliteit van de } \\
\text { verslaggeving, etc. } \\
\text { 2. Versterk ook overigens de communica- } \\
\text { tie tussen accountant en audit committee } \\
\text { door frequenter contact en door een ver- } \\
\text { plichte rapportage door audit committee } \\
\text { aan management waarin de bevindingen } \\
\text { van de controle en rol audit committee } \\
\text { daarin wordt besproken. }\end{array}$ & $\begin{array}{l}\text { Optie } 1 \text { en } 2 \text { als voorstel voor wetgeving } \\
\text { overgenomen. }\end{array}$ \\
\hline
\end{tabular}

zondheid van alle ondernemingen. Deze zekerheid zou de risico's op afwijkingen moeten verlagen en zo de kosten van faillissementen moeten verminderen, die anders ten laste zouden komen van de belanghebbenden van de onderneming en de maatschappij als geheel. Een solide auditfunctie is essentieel om het vertrouwen in de markt te herstellen; zij draagt bij aan de bescherming van beleggers en verlaagt de kapitaalkosten voor bedrijven" (European Commission, 2010, p. 3).

De Europese Commissie lijkt hier op twee gedachten te hinken. Enerzijds de gedachte dat het goed is om terug te gaan naar de pure retrospectieve controletaak van de jaarrekening en anderzijds de gedachte dat een verbreding van de rolinvulling noodzakelijk is. Deze innerlijke tegenstrijdigheid blijkt ook uit de argumentatie om de rolinvulling nader te analyseren en a priori de reikwijdte van de controle niet te verbreden. "Vanuit de gebruiker gezien, zouden auditors de belanghebbenden een zeer hoge mate van zekerheid moeten bieden met betrekking tot de onderdelen van de balans en de waardering van die onderdelen op de balansdatum. De Commissie wil onderzoek doen naar de 'back to basics'-benadering met een sterke nadruk op inhoudelijke verificatie van de balans en minder op naleving en de werking van systemen, m.a.w. de taken die hoofdzakelijk de verantwoordelijkheid moeten blijven van de cliënt en vooral vallen onder de interne controle" (European Commission, 2010, pp. 7).

In de conceptwetgeving van de Europese Commissie (2011a, 2011b) van november 2011 blijkt deze eenzijdige visie eveneens uit de voorstellen die zijn gedaan over de strikte scheiding tussen controle- en adviesdiensten. Hierin wordt controle gedefinieerd als de zogenoemde 'wettelijke controle' zonder dat is beoordeeld of de reikwijdte van de controle tegemoetkomt aan de verwachtin- 
gen die er bij stakeholders leven over de rolinvulling van de accountant. Hierdoor wordt een belangrijk aspect miskend, namelijk dat de maatstaf die aan de rolinvulling door de diverse groepen stakeholders wordt gesteld niet statisch is, zoals in paragraaf 1 besproken. Het is opmerkelijk dat dit aspect in de conceptwetgevingsvoorstellen nauwelijks aandacht krijgt. Uit een voorbereidend stuk van de EC waarin de resultaten van een stakeholderanalyse zijn opgenomen, wordt namelijk wel gerapporteerd dat er verschil van inzicht is over de verbreding van de rolinvulling, maar hierbij wordt geen nadere onderbouwing gegeven: "Some representatives of the profession suggested that the audit report should provide more forward-looking information and some more disclosures on risk, judgements and estimates, whereas public authorities strongly disagree on this point" (European Commission, 2011f, pp. 157). Het is teleurstellend dat de Europese Commissie deze resultaten niet verder heeft geanalyseerd en slechts in de marge melding maakt dat hier verschillende inzichten over bestaan tussen 'public authorities'. Nadere analyse van dit resultaat had het benodigde inzicht kunnen geven in de werkelijke vraag van stakeholders. Relevante vragen zijn of er onderscheid is in visie tussen de verschillende public authorities en op grond van welke argumenten zij het op dit punt eens of oneens zijn. Juist het vraagstuk over de tekortkomingen in de rolinvulling door accountants is de kern van het maatschappelijk debat. Komt Barnier tegemoet aan het kernvraagstuk van stakeholders?

Als de voorstellen van Barnier worden afgezet tegen de rapporten waarin de rol van de diverse betrokkenen bij de financiële crisis en ook de rol van de accountant is geëvalueerd (Commissie de Wit, 2010a, 2010b), dan lijken de voorstellen voor hervorming van het accountantsberoep op het eerste gezicht niet de complete oplossing te bieden voor het kernvraagstuk van stakeholders, namelijk dat stakeholders onvoldoende inzicht hebben in de financiële stabiliteit van een onderneming en de eventuele onzeker-

\section{Figuur 2 Exploring options for change in auditor reporting}

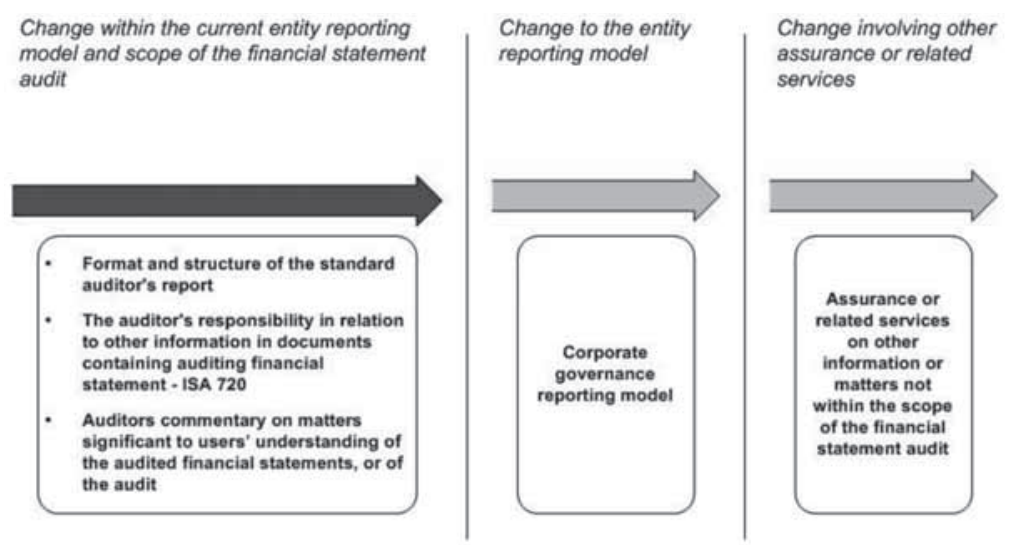

Figuur ontleend aan IAASB, 2011, p. 12 heden die deze financiële stabiliteit kunnen beïnvloeden. Een belangrijke vraag die in de voorstellen van de Europese Commissie nauwelijks wordt geraakt, betreft een toereikende rapportering door ondernemingen en de positie en rol van de diverse betrokkenen. Dit is vooral belangrijk voor de hernieuwing van de rolinvulling van de accountant om zo nieuwe verwachtingskloven te voorkomen.

In het vervolg van deze paragraaf zal worden ingegaan op een aantal consultaties en andere initiatieven die door verschillende instanties zijn opgepakt om inzicht in dit vraagstuk te krijgen.

\subsection{Initiatieven}

De IAASB heeft een consultatie gestart om input te krijgen op het huidige rapporteringsmodel, vanuit de perceptie dat stakeholders op dit moment onvoldoende informatie krijgen (IAASB, 2011, p. 8). In dit model wordt input gevraagd op de gehele keten van de huidige rapportering door ondernemingen en de daarbij behorende reikwijdte van de rapportering door de accountant, het governance model binnen een onderneming en ten slotte over de additionele aan de controle gerelateerde dienstverlening. Hierbij wordt uitgegaan van het bestaande rapporteringsmodel en de dienstverlening die accountants onder de huidige controlestandaarden en het assurance framework verrichten. De IAASB heeft haar consultatie in figuur 2 toegelicht.

Deze figuur geeft een goed inzicht in de complexiteit van het vraagstuk. De vereiste aanpassing van de rolinvulling gaat hand in hand met aanpassingen in het rapporteringsmodel door ondernemingen.

\subsection{Verbreding rapporteringsmodel}

Ook het Center for Audit Quality in de US heeft op basis van een dialoog met vertegenwoordigers van verschillende groepen belanghebbenden (analisten, bestuurders, RvCen auditcommissieleden, accountants, wetenschappers) geconstateerd dat de herijking van de rol van accountants afhankelijk is van enerzijds de behoefte van stakeholders aan zekerheid, maar anderzijds wordt bepaald door de mate waarin ondernemingen bereid zijn om de informatieverschaffing te verbeteren en aan te passen aan de informatievragen van de diverse stakeholders. "Moreover, participants commented that changes to the role of the auditor without corresponding action to improve weaknesses identified in the corporate reporting framework may not sufficiently respond to investor financial reporting concerns. [...] participants identified a number of disclosures that could be improved by management and/or might be appropriate for auditor association. The disclosures most commonly identified related to financial information contained in Management's Discussion and Analysis (MD\&A); the company's process for assessing risk and developing financial assumptions and estimates; the com- 
pany's critical judgments and accounting estimates; and the risk factors disclosure in the annual report" (Center for Audit Quality, 2011, pp. 3).

Diverse andere instanties hebben eveneens onderzoek gedaan naar de vraag of stakeholders belang hebben bij een bredere rapportering door ondernemingen en komen tot de conclusie dat onder andere beleggers, leden van de auditcommissie en CFO's belang hebben bij een meer zinvolle risicorapportage door ondernemingen, bijvoorbeeld door een integrale bespreking van het business model, de strategie, belangrijkste risico's en de beheersing daarvan (Financial Reporting Committee, 2011; MARC, 2010; NBA, 2011). De voorstellen die recent zijn gedaan voor een integrated report door de International Integrated Reporting Council (IIRC) worden daarbij als het toekomstige verslaggevingsmodel $^{1}$ genoemd. De Financial Reporting Review Panel heeft in het verlengde daarvan in februari 2011 opgeroepen tot een versterking en verbetering van de risicorapportering door ondernemingen.

\subsection{Aanpassing rolinvulling door accountants}

Beleggersvereniging Eumedion heeft, in een reactie op de consultatie van de IAASB, aangegeven dat zij van mening is dat de accountant in zijn controleverklaring beleggers veel vaker moet wijzen op de risico's waarvoor de onderneming zich geplaatst ziet. Daarbij moet de accountant de toelichtende paragraaf niet alleen gebruiken voor het benadrukken van financiële risico's, maar juist ook niet-financiële risico's, zoals risico's van het gehanteerde governance model, strategische risico's en duurzaamheidsrisico's (Eumedion, 2011).

De Nederlandse Beroepsorganisaties van Accountants (NBA) heeft in reactie op de maatschappelijke discussie een aantal voorstellen gedaan voor een concrete bredere invulling van de rol van de accountant. De NBA heeft in een adviesrapport over de verbreding van de rol van de accountant diverse voorstellen gedaan voor een verbreding van de rol van de accountant op het gebied van onderzoek naar risicomanagement van een onderneming, maatschappelijk verantwoord ondernemen, corporate governance, verplichte toekomstgerichte informatie in het jaarverslag en in het verslag van de raad van commissarissen. Ook worden voorstellen gedaan tot het verplicht daarover rapporteren door de accountant zowel intern aan de raad van commissarissen $(\mathrm{RvC})$ als extern in de toelichting bij de controleverklaring indien de onderneming en/of de $\mathrm{RvC}$ tekortschiet, bijvoorbeeld in de vereiste risicorapportage in het jaarverslag (NBA, 2011). Ten aanzien van dit laatste onderwerp heeft de NBA in februari 2012 een conceptpraktijkhandreiking uitgebracht die accountants hiervoor nadere richtlijnen en voorbeelden geeft. Ook de uitbreiding van de controle tot het verstrekken van assurance bij alle onderwerpen in een integrated report past in deze ontwikkeling.

\section{Samenvatting}

De rolinvulling van de accountant is onder invloed van de financiële crisis onder druk komen te staan. In diverse rapporten wordt kritiek gegeven of de accountant een adequate bijdrage levert aan de informatiebehoeften die er bij stakeholders leven ten aanzien van financiële stabiliteit van een onderneming. In dit artikel is vooral de vraag gesteld of de reikwijdte van de huidige rolinvulling toereikend is en of de voorstellen van Barnier voor hervorming van het accountantsberoep hierop een adequaat antwoord geven. Er is vastgesteld dat de huidige rolinvulling onder invloed van de gewijzigde informatiebehoefte van de verschillende groepen stakeholders en hun behoeften aan zekerheid over het functioneren van ondernemingen niet voldoet.

Dit vraagstuk dat stakeholders onvoldoende inzicht hebben in de financiële stabiliteit van een onderneming wordt in het hervormingsdebat over het accountantsberoep onderkend. Er is vervolgens geconcludeerd dat de voorstellen van Barnier te veel de nadruk leggen op de bestaande rolinvulling en te weinig aandacht geven aan de differentiatie in informatiebehoeften van de diverse soorten stakeholders. Ook is vastgesteld dat het in kaart brengen van de concrete informatiebehoeften nog onvoldoende is onderzocht en dat geldt ook voor de wijze waarop de rolinvulling van de accountant daarop kan worden aangepast. Op basis van eerste onderzoeken zijn er wel signalen dat deze informatiebehoefte breder is, vooral waar het gaat om informatie over risico's die een onderneming loopt en de wijze waarop een onderneming daarmee omgaat. Nader onderzoek waarbij in dialoog met stakeholders deze informatiebehoeften nader worden uitgewerkt, verdient zeer zeker navolging. Dat geldt vervolgens ook voor de nieuwe rolinvulling van de accountant. De recente voorstellen van de NBA kunnen daarbij als leidraad worden gebruikt.

Een nieuwe rolinvulling moet starten met een besef dat er differentiatie bestaat in de informatiebehoeften tussen de verschillende stakeholders. Vanuit dit besef speelt een aantal vragen die bepalend zijn voor de toekomstige rol van accountants. De eerste vraag betreft of het nodig is om in de dienstverlening en de reikwijdte van de werkzaamheden onderscheid te maken om an de differentiatie in vraagstelling tegemoet te komen. Op grond van de analyse in dit artikel kan deze vraag bevestigend worden beantwoord, wat betekent dat de accountant zijn controletaak moet verbreden. Voorbeelden hiervan zijn het in de reikwijdte van de controle betrekken van de beschrijving van de strategie, risico's en interne beheersingsystemen, zoals in het jaarverslag opgenomen. Een verdergaande ontwikkeling is de uitbreiding van de controle tot het verstrekken van assurance bij alle onderwerpen in een integrated report. 
Een ander aspect dat daaruit volgt, is of het nodig is om in de rapportering over de uitkomsten van de werkzaamheden rekening te houden met de differentiatie in vraagstukken. Dit omvat het verstrekken van verschillende rapportages en/of het nadrukkelijker in de rapportering benoemen van verschillende onderwerpen. Ook deze vraag kan op basis van bovenstaande analyse bevestigend worden beantwoord, wat betekent dat de eenduidige controleverklaring niet langer het antwoord kan zijn op de verscheidenheid aan vraagstukken die leven bij stakeholders. Andere en meerdere vormen van rapportering aan diverse groepen stakeholders, zowel binnen de onderneming als naar de externe stakeholder, zijn een logisch gevolg van deze tendens naar differentiatie in informatiebehoeften van stakeholders als het gaat om de financiële stabiliteit van een onderneming. Dat betekent dat de controleverklaring niet het enige medium is waarmee een accountant extern over zijn werkzaamheden zou moeten rapporteren. Dit model miskent namelijk de breedheid in vraagstukken van diverse groepen stakeholders.

\section{Aanbevelingen}

Voor de toekomst is de belangrijkste uitdaging voor de accountant om zijn rol op basis van een dialoog met de diverse stakeholders continu aan te passen op het bredere stakeholdermodel zoals dat in de hedendaagse maatschappij zijn inbedding heeft gekregen. De conceptwetgevingsvoorstellen van Barnier lijken hier weinig of geen concrete aanknopingspunten voor te bieden. De NBA vervult met de recent gedane voorstellen een voortrekkersrol op het gebied van verbreding van de rolinvulling door de ac- countant. Het is aan te bevelen om deze inzichten breder in Europees verband in de discussie in te brengen. Immers het maatschappelijk vertrouwen in de financiële stabiliteit van een onderneming is van meerdere aspecten afhankelijk dan uitsluitend de financiële performance van een onderneming (o.a. Commissie de Wit 2010a, 2010b). Eveneens volgt uit het stakeholdermodel dat de informatiebehoeften van de diverse groepen stakeholders uiteenlopend zijn en zich aanpassen onder invloed van de economische omstandigheden. Dat betekent dat de invulling van de rol die de accountant heeft naar deze diverse groepen stakeholders dus ook verschillend moet en kan zijn. Voor de toekomst van het beroep is het daarom essentieel om deze behoeften in dialoog met de stakeholders scherp in kaart te brengen en daarop zowel het controlemodel als de wijze van communicatie en rapportage door accountants aan te passen. De huidige voorstellen van Barnier komen daaraan onvoldoende tegemoet aangezien deze in belangrijke mate voorbijgaan an het werkelijke vraagstuk van gebrek aan informatie van stakeholders over de financiële stabiliteit van een onderneming en de daarmee gelijklopende ontwikkeling in de informatiebehoefte en behoefte aan zekerheid van stakeholders.

Een belangrijke randvoorwaarde voor deze verbreding van de rolinvulling is de aanpassing van het rapporteringsmodel zoals door de IAASB voorgesteld. Een belangrijk aspect daarvan is de versterking van de risicorapportering onder andere door de materiële naleving van de best practicebepalingen in de Corporate Governance Codes over dit onderwerp te verbeteren.

\section{Noten}

Zie themanummer MAB, november 2011

\section{Literatuur}

- Adviescommissie Toekomst Banken (Commissie de Maas) (2009), Naar herstel van vertrouwen, zie: http://www.nub.n//scrivo/ asset.php?id=534862.

- Brown, R. (ed.) (1905/2006), A history of accounting and accountants, Edinburgh: T.T. and E.C. Jack.

- Carmichael, D.R. (2004), The PCAOB and the social responsibility of the independent auditor, Accounting Horizons, vol. 18, no. 2 (juni), pp. 127-133.

- Center for Audit Quality (2011), Observations on the evolving role of the auditor, a summary of stakeholder discussions, zie: http:// www.thecaq.org/publications/ EvolvingRoleoftheAuditor.pdf.
- Commission on Auditors' Responsibilities (1978), Report, conclusions, and recommendations, New York.

- Eumedion, NBA en VBA (2011), De aandeelhouderswaarde van de accountant, Amsterdam.

- Eumedion (2011), Eumedion response to the consultation paper on enhancing the value of auditor reporting: Exploring options for change Amsterdam; zie: http://www.ffac.org/sites/ default/files/publications/exposure-drafts/ comments/5536-response-laasbconsultati.pdf.

- European Commission (2010), Audit policy: Lessons from the crisis, green paper, Brussel; zie: http://eur-lex.europa.eu/LexUriServ/
LexUriServ.do?uri=COM:2010:0561:FIN:EN: PDF.

- Europese Commissie (2011a), Voorstel voor een Verordening van het Europees Parlement en De Raad betreffende specifieke eisen voor de wettelijke controles van financiële overzichten van organisaties van openbaar belang, Brussel; zie: http://ec.europa.eu/ internal_market/auditing/docs/reform/ regulation_nl.pdf.

- Europese Commissie (2011b), Voorstel voor een Richtlijn van het Europees Parlement en De Raad tot wijziging van Richtlijn 2006/43/ EG betreffende de wettelijke controles van jaarrekeningen en geconsolideerde jaarrekeningen, Brussel; zie: 
http://ec.europa.eu/internal_market/auditing/ docs/reform/directive_nl.pdf.

- European Commission (2011c), Press release: Restoring confidence in financial statements: the European Commission aims at a higher quality, dynamic and open audit market, Brussel; zie: http://europa.eu/rapid/ pressReleasesAction.do? reference $=\mid \mathrm{P} / 11 /$ 1480\&format=PDF\&aged=1 \&language=EN\&guilanguage $=e n$.

- European Commission (2011d), Reforming the audit market - frequently asked questions, Brussel; zie: http://europa.eu/rapid/ pressReleasesAction.do? reference=MEMO/11/ 856\&format=PDF\&aged=1\&language $=E$ \& guilanguage $=e n$.

- Europese Commissie (2011e), Toelichting op de effectbeoordeling - samenvatting, SEC (2011) 1385, Brussel; zie: http:// www.europarl.europa.eu/RegData/ docs_autres_institutions/ commission_europeenne/sec/2011/1385/ COM_SEC(2011)1385_NL.pdf.

- European Commission (2011f), Impact assessment - full text, SEC (2011) 1384, Brussel; zie: http://ec.europa.eu/governance/ impact/ia_carried_out/docs/ia_2011/ Sec_2011_1384_en.pdf.

- Europees Parlement (2011), Resolutie van het Europees Parlement van 13 september 2011 over het beleid inzake controle van financiële overzichten: lessen uit de crisis (2011/2037 (INI)), Straatsburg; zie: http:// www.europarl.europa.eu/sides/getDoc.do? pubRef=-//EP//NONSGML+REPORT+A72011-0200+0+DOC+PDF+VO//NL.

- Financial Reporting Council (2011), Boards and risk, a summary of discussions with companies, investors and advisers, London; zie: http://www.frc.org.uk/images/uploaded/ documents/Boards\%20and\%20Risk\% 20final.pdf.

- Institute of Chartered Accountants in England \& Wales (2005), Audit quality: Agency theory and the role of audit, London; zie: http://
www.icaew.com/\%/media/Files/Technical/ Audit-and-assurance/audit-quality/auditquality-forum/agency-theory-and-the-role-ofaudit.ashx.

- Institute of Chartered Accountants in England \& Wales (2010), The future of audit; the big debate, Accountancymagazine.com, juli, pp. 96-99.

- Institute of Chartered Accountants in England \& Wales (2011), The future of audit. Enhancing quality, confidence and innovation, London; zie: http://uww.icaew.com/en/ technical/audit-and-assurance/the-future-ofaudit.

- International Auditing and Assurance Standards Board (2011), Enhancing the value of auditor reporting: Exploring options for change, consultation paper, New York; zie: http://www.ffac.org/sites/default/files/ publications/exposure-drafts/ CP_Auditor_Reporting-Final.pdf.

- Jensen, M.C. en W.H. Meckling (1976), Theory of the firm: Managerial behavior, agency costs and ownership structure, Journal of Financial Economics, vol. 39, pp. 305-360.

- Limperg, Jr., Th. (1932/1933), De functie van de accountant en de leer van het gewekte vertrouwen, Maandblad voor Accountancy en Bedrijfshuishoudkunde, februari en oktober 1932, oktober en november 1933; herdrukt in de bundel: "1924 MAB 1960 inhoudende een aantal bijdragen gedurende deze jaren verschenen in het Maandblad voor Accountancy en Bedrijfshuishoudkunde", deel 2, Accountancy, Purmerend: Muusses, pp. 137-169.

- Maastricht Accounting, Auditing and Information Management Research Centre (2010), The value of audit; zie: http:// www.maastrichtuniversity.n/web/Main/ Sitewide/News1/

NewReportFromMARCValueOfAudit.htm

- Nederlandse Beroepsorganisatie van Accountants (NBA) (2011), Adviesrapport: Verbreding Poortwachtersfunctie; Meer zekerheid bij meer informatieve rapportages, Amsterdam; zie: http://www.nba.nl/ Documents/Maatschappelijk\%\%2Odebat/ NBA_Adviesrapport_Poortwachter_ okt2011.pdf.

- Nederlandse Beroepsorganisatie van Accountants (NBA) (2012). Concept Praktijkhandleiding 1119, Amsterdam; zie: http://www.nba.nl/Documents/ Praktijkhandreikingen/ Conceptpraktijkhandreiking1119.pdf.

- Public Company Accounting Oversight Board (2011), Concept Release on possible Revisions to PCAOB Standards related to Reports on Audited Financial Statements and related Amendments to PCAOB Standards, PCAOB Release No. 2011-003, Washington; zie: http://pcaobus.org/Rules/Rulemaking/ DocketO34/Concept_Release.pdf.

- Select Committee on Economic Affairs (2011), Auditors: Market concentration and their role, volume I: Report, zie: http:// www.parliament.uk/hleconomicaffairs

- Tweede Kamer der Staten-Generaal (Commissie de Wit) (2010a), Parlementair onderzoek financieel stelsel, Deelonderzoek 1 en 2, Den Haag; zie: http:// www.rijksoverheid.nl/onderwerpen/ hervorming-financieel-stelsel/onderzoekfinancieel-stelsel.

- Tweede Kamer der Staten-Generaal (Commissie de Wit) (2010b), Parlementair onderzoek financieel stelsel, Rapport, Den Haag; zie: http://www.rijksoverheid.nl/ onderwerpen/hervorming-financieel-stelsel/ onderzoek-financieel-stelsel.

- Wallage, P. (2005), De actuele waarde van het Limpergiaans vertrouwen, Maandblad voor Accountancy en Bedrijfseconomie, vol. 79, no. 4 (april), pp. 125-131.

- Watts, R.L. en J.L. Zimmerman (1983), Agency problems, auditing and the theory of the firm: some empirical evidence, The Journal of Law \& Economics, vol. 26 (oktober), pp. 613-634. 